\title{
Peningkatan Motivasi dan Hasil Belajar IPS Melalui Model Pembelajaran Problem Based Learning
}

\author{
Siti Nuriyah \\ SMP Negeri 2 Blitar Jawa Timur Indonesia \\ Email: Snuriyahsiti08@gmail.com
}

\begin{abstract}
Abstrak: Dalam kurikulum 2013 pada prinsip pelaksanaan adalah berpusat pada peserta didik yang berbasis aktifitas yang memberikan kesempatan untuk mengembangkan potensi minat dan bakatnya dalam bidang yang ditekuninya secara mandiri. Upaya memandirikan siswa untuk belajar, bekerja sama, dan menilai diri sendiri diutamakan agar siswa mampu membangun kemauan, pemahaman, dan pengetahuannya. Peningkatan potensi, kecerdasan, dan motivasi siswa perlu terusmenerus diupayakan dengan cara proses pembelajaran yang direncanakan oleh guru. Upaya yang dilakukan guru adalah menggunakan model Problem Based Learning (PBL) sangat cocok untuk memotivasi siswa dalam memecahkan masalah masalah terkait dengan

\begin{tabular}{l}
\hline Tersedia Online di \\
\hline http://journal.unublitar.ac.id/pendidi \\
\hline kan/index.php/Riset_Konseptual \\
\hline Sejarah Artikel \\
\hline Diterima pada : 17-01-2020 \\
Disetuji pada : 28-04-2020 \\
Dipublikasikan pada : 30-04-2020 \\
\hline Kata Kunci: \\
\hline motivasi, hasil belajar, problem based \\
learning \\
DOI: \\
\hline http://doi.org/10.28926/riset_konseptual.v4i \\
2.187
\end{tabular}
materi Pengaruh perubahan dan interaksi keruangan terhadap kehidupan di negara negara ASEAN. Dengan menggunakan model Problem Based Learning (PBL) peserta didik dapat meningkatkan pengetahuan dan pemahaman dalam pembelajaran Ilmu Pengetahuan Sosial secara keseluruhan.
\end{abstract}

\section{PENDAHULUAN}

Kehidupan manusia terus mengalami perubahan sesuai dengan perkembangan teknologi. Semakin hari berbagai penemuan penemuan baru terkait dengan perkembangan teknologi informasi dan komunikasi, seperti model produk alat alat komunikasi. Hal tersebut membawa dampak interaksi manusia semakin digantikan dengan media media informasi dan komunikasi. Arus globalisasi membawa dampak jarak dan waktu antar negara bukan menjadi suatu penghalang yang serius, perkembangan informasi bisa diketahui dari berbagai media informasi dan komunikasi dewasa ini. Polemik dan permasalahan yang terjadi sekarang ini menghadapi isu isu global dalam rangka pasar bebas dunia ini dapat kita rasakan pengaruh dan dampaknya, seperti mendorong tumbuhnya perdagangan bebas (AFTA) di kawasan negara negara ASEAN. AFTA mendorong terpacunya perkembangan industri, perdagangan dan tenaga kerja. Produktifitas dari negara negara ASEAN secara bebas bisa terjadi hubungan perdagangan antar sesama negara anggota. Menghadapi perkembangan perdagangan bebas tersebut membutuhkan interaksi yang terjalin kerjasama antar negara anggota. Setiap negara anggota ASEAN saling terikat dan saling membutuhkan baik dalam hubungan kerjasama ekonomi, politik sosial dan budaya yang tercantum dalam pilar ASEAN. Cakrawala inilah yang harus kita ketahui agar siswa kita kedepan mampu untuk menghadapi pengaruh arus globalisasi menyongsong pasar bebas dunia .

Perkembangan zaman bukan semakin mudah dalam menghadapi Tantangan yang semakin ketat dalam arus global, daya saing dalam perdagangan bebas semakin luas. Hidup kedepan ini bukan semakin mudah melainkan semakin besar tantangannya. Hanya satu yang dibutuhkan untuk menjawab tantangan adalah dengan 
peningkatan kualifikasi dan kompetensi sesuai dengan bidang yang miliki. Dalam pembelajaran terjadi perubahan kurikulum tiap sepuluh tahun sekali adalah untuk menjawab tantangan kehidupan peserta didik dimasa yang akan datang, agar mampu berkompetisi sesuai dengan minat dan bakat yang dimilikinya. Peserta didik dihadapkan berbagai persoalan bagaimana mampu untuk mengatasi dan memecahkan masalah masalah yang terjadi di lingkungan masyarakat sekarang ini. Kondisi tersebut sangat tepat apabila model pembelajaran Problem Based learning $(P B L)$ dapat diterapkan dalam pembelajaran IImu Pengetahuan Sosial (IPS). IImu pengetahuan sosial merupakan ilmu yang bersifat multidimensional yang mencakup beberapa bidang dalam segi kehidupan berbangsa dan bernegara.

\section{Pembelajaran berbasis masalah (PBM) \\ HASIL dan PEMBAHASAN}

Pembelajaran berbasis masalah (PBM) mendorong peserta didik dengan kritis dapat menemukan masalah, menginterpretasikan masalah, mengidentifikasi faktor penyebab terjadinya masalah, mengidentifikasi informasi dan menemukan strategi yang diperlukan untuk mnyelesaikan masalah, mengevaluasi kesesuaian solusi dengan strategi dan mengkomunikasikan kesimpulan.

Pembelajaran berbasis masalah (PBM) atau dalam bahasa Inggris disebut Problem Based Learning (PBL) dikembangkan pertama kali oleh Howard Barrows di awal tahun 70 - an dalam pembelajaran ilmu pengetahuan medis di Southern illinois University school. Para siswa mempelajari seseorang yang mempunyai penyakit untuk dicari penyembuhannya. Dalam perjalannya terus meluas ke pelajaran Ilmu Pengetahuan Alam di perguruan tinggi kemudian meluas ke sekolah sekolah menengah dan berkembang pula dapat digunakan untuk pembelajaran IImu Pengetahuan Sosial (IPS).

Pendapat lain menurut John Dewey kritikus sosial dan pemikir dalam bidang pendidikan pernah mengatakan bahwa pembelajaran berbasis masalah merupakan proses interaksi antara stimulus dan respon. Peserta didik diberikan masalah oleh lingkungannya kemudian diinvestigasi, di nilai, di analisa, serta dicari solusinya. Peserta didik diberikan masalah masalah nyata saat awal pembelajaran atau proses pembelajaran di kegiatan inti. Dalam kegiatan inti pada kurikulum 2013 yang menggunakan pendekatan saintifik yaitu langkah pertama adalah mengamati, dalam kegiatan mengamati tersebut peserta didik diberi permasalahan untuk diteliti dan dicari solusinya. Tujuannya agar peserta didik dapat meningkatkan ketrampilan berfikir kritis dalam menyelesaikan masalah untuk mendapatkan konsep konsep penting dalam pelajaran Ilmu pengetahuan Sosial (IPS).

Model pembelajaran Problem Based learning (PBL) secara skematik mengacu kepada prinsip prinsip pembelajaran lainnya seperti pembelajaran berbasis proyek (Project-Based learning); pembelajaran berbasis pengalaman (experiencebased-learning) pembelajaran authentik (Authentic Learning) dan dan pembelajaran bermakna (Anchored Instruction) buku guru, 2018: 14. Landasan teori model pembelajaran problem based Learning (PBL) adalah: teori Dewey tentang kelas berorientasi masalah; konstruktivisme Piaget dan Vygotsky; serta belajar penemuan menurut Bruner. Efek pembelajaran model Problem Based learning (PBL) adalah pencapaian kompetensi berupa ketrampilan inkuiri dan pemecahan masalah, perilaku berperan orang dewasa, dan ketrampilan belajar mandiri (independen).

Dalam model Problem Based Learning ( PBL), fokus pembelajaran ada pada masalah yang dipilih sehingga pembelajar tidak saja mempelajari konsep-konsep yang berhubungan dengan masalah tetapi juga metode ilmiah untuk memecahkan masalah tersebut. Peserta didik tidak saja harus memahami konsep yang relevan dengan masalah yang menjadi pusat perhatian tetapi juga memperoleh pengalaman belajar yang berhubungan dengan ketrampilan menerapkan metode ilmiah dalam pemecahan masalah dan menumbuhkan pola berpikir kritis. 
Problem Based Learning (PBL) dimulai dengan suatu masalah yang memicu ketidaksetimbangan kognitif pada diri peserta didik. Keadaan ini dapat mendorong rasa ingin tahu sehingga memunculkan bermacam-macam pertanyaan disekitar masalah yang dikerjakan. Bila pertanyaan-pertanyaan tersebut telah muncul dalam diri pesera didik maka motivasi intrinsik mereka untuk belajar akan tumbuh. Pada kondisi tersebut diperlukan peran guru sebagai fasilitator untuk mengarahkan peserta didik tentang pengetahuan apa yang diperlukan untuk memecahkan masalah, apa yang harus dilakukan, atau bagaimana melakukannya dan seterusnya. Penerapan Problem Based Learning (PBL) dalam pembelajaran dapat mendorong peserta didik mempunyai inisiatif untuk belajar secara mandiri. Pengalaman ini sangat diperlukan dalam kehidupan sehari-hari dimana berkembangnya pola pikir dan pola kerja seseorang bergantung pada bagaimana dia membelajarkan dirinya. Lebih lanjut. Problem Based Learning (PBL) juga bertujuan untuk membantu peserta didik belajar secara mandiri. Pembelajaran Problem Based Learning (PBL) dapat diterapkan bila didukung lingkungan belajar yang konstruktivistik.

Dalam buku guru: IImu pengetahuan Sosial kelas IX (2018) mengemukakan ada 5 tahap yang perlu dilakukan untuk mengimplementasikan model pembelajaran Problem Based Learning ( PBL). Tahap-tahap tersebut merujuk pada tahap-tahapan praktis yang dilakukan dalam kegiatan pembelajaran dengan Problem Based Learning (PBL) sebagaimana disajikan di bawah ini.

Tahap pertama adalah mengorientasikan siswa pada masalah, Pembelajaran dimulai dengan menjelaskan tujuan pembelajaran dan aktivitas-aktivitas yang akan dilakukan. Dalam penggunaan model pembelajaran Problem Based Learning (PBL), tahapan ini sangat penting dimana guru harus menjelaskan dengan rinci apa yang harus dilakukan oleh peserta didik dan juga oleh guru. Disamping proses yang akan berlangsung, sangat penting juga dijelaskan bagaimana guru akan mengevaluasi proses pembelajaran. Hal ini sangat penting untuk memberikan motivasi agar siswa dapat terlibat dalam pembelajaran yang akan dilakukan. Siswa dilatih untuk terlibat langsung dan mempunyai cara untuk menyelesaikan masalah yang ada dalam proses pembelajaran materi pengaruh perubahan dan interaksi keruangan terhadap kehidupan di negara negara ASEAN terutama tentang faktor penyebab interaksi antar negara negara anggota ASEAN. Yang menjadi penyebab interaksi antar negara anggota asean adalah dapat disebabkan oleh faktor alam, faktor iklim, faktor geografi dan faktor budaya. Dari berbagai faktor tersebut dapat dituangkan dalam bentuk interaksi antar negara negara anggota ASEAN, Agar terjaling hubungan kerjasama yang saling membantu dan dapat memenuhi kebutuhan semua bidang ekonomi, politik, sosial maupun budaya.

Tahap kedua adalah mengorganisasikan peserta didik untuk belajar Disamping mengembangkan ketrampilan memecahkan masalah, pembelajaran Problem Based Learning (PBL) juga mendorong peserta didik belajar berkolaborasi. Pemecahan suatu masalah sangat membutuhkan kerjasama antar anggota. Guru dapat memulai kegiatan pembelajaran dengan membentuk kelompok-kelompok siswa dimana masingmasing kelompok akan memilih dan memecahkan masalah yang berbeda. Prinsipprinsip pengelompokan peserta didik dalam pembelajaran kooperatif dapat digunakan dalam konteks ini seperti: kelompok harus heterogen, pentingnya interaksi antar anggota, komunikasi yang efektif, adanya tutor sebaya, dan sebagainya. Guru sangat penting memonitor dan mengevaluasi kerja masing-masing kelompok untuk menjaga kinerja dan dinamika kelompok selama pembelajaran. Setelah siswa diorientasikan pada suatu masalah dan telah membentuk kelompok belajar, selanjutnya guru dan siswa menetapkan subtopik-subtopik yang spesifik, tugas-tugas penyelidikan, dan jadwal. Tantangan utama bagi guru pada tahap ini adalah mengupayakan agar semua siswa aktif terlibat dalam sejumlah kegiatan penyelidikan dan hasil-hasil penyelidikan ini dapat menghasilkan penyelesaian terhadap permasalahan terutama dalam pengaruh perubahan dan interaksi keruangan terhadap kehidupan negara negara 
ASEAN. Peserta didik berkolaborasi memecahkan tentang faktor penyebab interaksi antar negara - negara anggota ASEAN.

Tahap ketiga membimbing penyelidikan individual ataupun kelompok. Dalam model Problem Based Learning (PBL) ada penyelidikan. Mungkin saja setiap situasi permasalahan memerlukan teknik penyelidikan yang berbeda, namun pada umumnya tentu melibatkan karakter yang identik, yakni pengumpulan data dan eksperimen, berhipotesis dan penjelasan, serta memberikan pemecahan. Pengumpulan data dan eksperimentasi merupakan aspek yang sangat penting. Pada tahap ini, guru harus mendorong peserta didik untuk mengumpulkan data dan melaksanakan eksperimen (mental maupun aktual) sampai mereka betul-betul memahami dimensi situasi permasalahan. Tujuannya adalah agar peserta didik mengumpulkan cukup informasi untuk menciptakan dan membangun ide mereka sendiri. Pada tahap ini seharusnya lebih dari sekedar membaca tentang masalah-masalah dalam buku-buku. Guru membantu peserta didik untuk mengumpulkan informasi sebanyak-banyaknya dari berbagai sumber, dan guru seharusnya mengajukan pertanyaan pada pembelajar untuk berifikir tentang masalah dan ragam informasi yang dibutuhkan untuk sampai pada pemecahan masalah yang dapat dipertahankan. Setelah peserta didik mengumpulkan cukup data dan memberikan permasalahan tentang fenomena yang mereka selidiki, selanjutnya mereka mulai menawarkan penjelasan dalam bentuk hipotesis, penjelasan, dan pemecahan. Selama pengajaran pada tahap ini, guru mendorong peserta didik untuk menyampikan semua ide-idenya dan menerima secara penuh ide tersebut. Guru juga mendorong siswa untuk mendapatkan penjelasan dan pemecahan masalah tentang pengaruh perubahan dan interaksi keruangan terhadap kehidupan negara negara ASEAN.

Tahap keempat mengembangkan dan menyajikan hasil karya, Tahap penyajian diikuti dengan menciptakan hasil karya dan memamerkannya. Hendaknya hasil karya lebih dari sekedar laporan tertulis, melainkan dapat berupa suatu laporan, videotape (yang menunjukkan situasi masalah dan pemecahan yang diusulkan), model (perwujudan secara fisik dari situasi masalah dan pemecahannya), program komputer, dan sajian multimedia. Tentunya kecanggihan hasil karya sangat dipengaruhi tingkat berfikir peserta didik. Selanjutnya adalah memamerkan hasil karya peserta didik tentang pengaruh perubahan dan interaksi keruangan terhadap kehidupan negara negara ASEAN guru berperan sebagai organisator pameran dari hasil karya peserta didik tersebut.

Tahap kelima menganalisa dan mengevaluasi proses pemecahan masalah, tahap ini merupakan tahap akhir dalam model pembelajaran Problem Based Learning (PBL). Tahap ini dimaksudkan untuk membantu peserta didik menganalisis dan mengevaluasi proses mereka sendiri dan keterampilan penyelidikan dan intelektual yang mereka gunakan. Selama tahap ini guru meminta peserta didik untuk merekonstruksi pemikiran dan aktivitas yang telah dilakukan selama proses kegiatan belajarnya. Kapan mereka pertama kali memperoleh pemahaman yang jelas tentang situasi masalah? Kapan mereka yakin dalam pemecahan tertentu? Mengapa mereka dapat menerima penjelasan lebih siap dibanding yang lain? Mengapa mereka menolak beberapa penjelasan? Mengapa mereka mengadopsi pemecahan akhir dari mereka? Apakah mereka berubah pikiran tentang situasi masalah ketika penyelidikan berlangsung? Apa penyebab perubahan itu? Apakah mereka akan melakukan secara berbeda di waktu yang akan datang? Tentunya masih banyak lagi pertanyaan yang dapat diajukan untuk memberikan umpan balik dan menginvestigasi kelemahan dan kekuatan model Problem Based Learning (PBL) dalam pembelajaran IImu Pengetahuan Sosial (IPS) tentang pengaruh perubahan dan interaksi keruangan terhadap negara - negara ASEAN. Dalam pembelajaran IPS yang menggunakan model pembelajaran Problem Based Learning ( $P B L)$ dapat mendorong siswa mempelajari materi pengaruh perubahan dan interaksi keruangan terhadap kehidupan di negara negara ASEAN. 


\section{Motivasi Belajar}

Motivasi merupakan unsur utama dalam melakukan sesuatu. Belajar tanpa motivasi akan terasa tiada artinya, seperti berlayar tanpa tujuan. Motivasi harus ada bagi peserta didik dalam proses pembelajaran. Motivasi itu bisa dari dalam diri sendiri maupun dari orang lain. Yang terpenting adalah dapat menguatkan dirinya dalam mengikuti proses pembelajaran di dalam kelas terutama dalam materi tentang pengaruh perubahan dan interaksi keruangan terhadap kehidupan negara negara ASEAN.

Mengutip dari bukunya Slameto yang berjudul belajar dan faktor faktor yang mempengaruhinya bahwa motivasi menurut Eysenck dan kawan kawan dirumuskan sebagai suatu proses yang menentukan tingkatan kegiatan, intensitas, konsistensi, serta arah umum dari tingkah laku manusia. Motivasi juga sama seperti konsep dengan minat, konsep diri, sikap dan sebagainya. Dalam pembelajaran motivasi dan minat itu harus muncul dalam dirinya tanpa pengaruh dari orang lain. Peran seorang guru harus bisa menumbungkan motivasi yang kuat agar tercipta suasana kegiatan belajar mengajar dengan menyenangkan sehingga dapat menyerap IImu Pengetahuan Sosial (IPS) terutama dalam materi pengarih perubahan dan interaksi keruangan negara negara ASEAN.

Motivasi harus dibangkitkan oleh diri sendiri dari dalam peserta didik, faktor dari luar juga dapat membangkitkan motivasi seperti guru diharapkan dapat membangkitkan peserta didik di dalam kelas. Fungsi seorang harus dapat sebagai motivator yang ulung untuk peserta didiknya. Membangkitkan motivasi siswa dapat dilakukan dengan cara (1) Mengaitkan topik yang dibahas dengan kegunaannya di masyarakat, di tempat kerja, dan di bidang ilmu pengetahuan dan teknologi. (2) Memberi kesempatan mendapatkan hasil yang baik (sense of succses). (3) Menggunakan variasi metode dalam proses pembelajaran. (4) Mengaitkan materi baru dengan materi lama.

Motivasi belajar juga berkaitan erat dengan minat peserta didik dalam pembelajaran. Apabila siswa mempunyai motivasi yang tinggi maka ia akan: a) memperlihatkan minat dan mempunyai perhatian; b) bekerja keras dan memberikan waktu kepada usaha tersebut; c) terus bekerja sampai tugas terselesaikan.

Motivasi adalah daya penggerak yang mendorong seseorang untuk melakukan sesuatu dengan tujuan tertentu. Motivasi terbaik adalah motivasi intrinsik, suatu motivasi yang tumbuh dari kesadaran diri pribadi sendiri yang didorong oleh cita-cita atau harapan pribadi. Motivasi ekstrinsik adalah motivasi yang tumbuh karena pengaruh dari luar. Misalnya untuk memotivasi siswa pada awal pembelajaran dapat digunakan cerita menarik, masalah menantang, sejarah, gambar menarik, aplikasi konsep dan sebagainya. Untuk proses belajar mengajar, motivasi intrinsik lebih menguntungkan karena biasanya dapat bertahan lebih lama. Motivasi ekstrinsik dapat diberikan oleh guru dengan jalan mengatur kondisi dan situasi belajar yang kondusif. Dengan memberikan jalan penguatan (reinforcement) maka motivasi yang mula-mula bersifat ekstrinsik lambat laun diharapkan akan berubah menjadi motivasi intrinsik (Dikdasmen,2005). Selanjutnya motivasi dan minat belajar akan mempengaruhi hasil belajar yang akan dicapai.

Effendi dan Praja (1985:72) berpendapat bahwa motivasi mendorong individu untuk mencapai tujuan itu, jelas dan berarti bagi individu, ia akan berusaha untuk mencapainya. Dengan perkataan lain dapat dirumuskan semakin jelas dan berarti tujuan yang diinginkan akan tercapai, semakin besar minat untuk mencapainya. Adapun fungsi dan tujuan motivasi belajar siswa adalah sebagai berikut: (1) Mendorong manusia untuk bertindak dalam hal ini perhatian adalah sebagai penggerak bagi individu untuk melakukan sesuatu. (2) Menentukan arah perbuatan yakni ke arah perbuatan yang dicita-citakan juga mencegah penyelewengan dari jalan yang ditempuh. (2) Menyeleksi perbuatan kita, artinya menyeleksi perbuatan mana yang 
harus dilakukan dan menyampingkan perbuatan yang menyimpang dari tujuan. Selanjutnya motivasi merupakan suatu proses yang dapat: (1) Membimbing anak didik ke arah pengalaman di mana kegiatan belajar itu berlangsung. (2) Memberikan kepada anak didik kita suatu kegiatan dan aktivitas yang memadai. (3) Pada suatu saat mengerakkan minat mereka terhadap suatu tujuan (Sutadipura, 1983: 114).

Motivasi belajar terbagi dua, yaitu motivasi instrinsik dan motivasi ekstrinsik, motivasi instrinsik adalah motivasi yang datang dari dalam diri individu, sedangkan motivasi ekstrinsik adalah motivasi yang datang dari luar diri individu.

Winkel (1986: 22) berpendapat mengenai motivasi belajar yaitu motivasi instrinsik adalah suatu bentuk motivasi yang di dalamnya aktivitas belajar dimulai dan dilanjutkan berdasarkan suatu dorongan secara mutlak berkaitan dengan aktivitas belajar. Minat ekstrinsik adalah bentuk minat yang di dalamnya aktivitas belajar yang dimulai dan diteruskan berdasarkan suatu dorongan yang tidak mutlak berkaitan dengan aktivitas belajar.

Beberapa tergolong motivasi instrinsik, yaitu : (1) Menjelaskan mengapa suatu mata pelajaran diajarkan dan apa kegunaannya untuk kehidupan kelak. (2) Menurunkan antusiasme dalam mengerjakan hal yang dipegang dan menggunakan prosedur yang dipegang. (3) Mengajukan bahan-bahan pelajaran yang tidak terlalu mudah namun tidak terlalu sukar. (4) Menjaga disiplin belajar di dalam kelas, memberikan hasil PR dan ulangan dalam waktu sesingkat mungkin.

Selanjutnya yang tergolong motivasi belajar ekstrinsik adalah sebagai berikut : Memenuhi tuntunan dari suatu kewajiban "tugasku adalah belajar". (1) Menghindari hukuman yang telah diancamkan kalau tidak belajar. (2) Memperoleh hadiah material yang telah dijanjikan jika belajar rajin. (3) Mendapat pujian jika hasil belajar baik. (4) Menjaga dan meningkatkan gengsi jika berhasil dalam belajar (W.S. Winkel, 1986: 26)

Dengan adanya beberapa cara untuk meningkatkan motivasi belajar siswa, maka diharapkan hasil belajar anak akan meningkat, dan tujuan pembelajaran akan tercapai secara optimal. Menurut Gage \& Berliner (1979) dalam bukunya Slameto dalam belajar dan faktor faktor yang mempengaruhinya, menyarankan cara memotivasi siswa tanpa harus melakukan reorganisasi kelas secara besar besaran adalah (1) pergunakan pujian Verbal,(2) pergunakan tes dalam nilai secara bijaksana, (3) bangkitnya rasa ingin tahu siswa dan keinginannya untuk mengadakan eksplorasi, (4) merangsang hasrat siswa dengan jalan memberikan pada siswa sedikit contoh hadiah yang akan diterimanya bila ia berusaha untuk belajar, (5) agar siswa lebih mudah memahami bahan pengajaran pergunakan materi materi yang sudah dikenal sebagai contoh, (6) terapkan konsep konsep atau prinsip prinsip dalam konteks yang yang unik dan luar biasa, agar siswa jadi lebih terlibat, (7) minta pada siswa untuk mempergunakan hal hal yang sudah dipelajari sebelumnya, (8) pergunakan simulasi dan permainan. Guru harus bisa membangkitkan motivasi siswa agar hasil belajar IImu Pengetahuan Sosial (IPS) dalm sub bidang pengaruh perubahan dan interaksi keruangan terhadap kehidupan negara - negara ASEAN.

\section{Hasil Belajar IImu Pengetahuan Sosial (IPS)}

Arends (2004) menyatakan bahwa ada tiga hasil belajar (out comes) yang diperoleh peserta didik yang diajar dengan Problem Based Learning (PBL) yaitu: (1) inkuiri dan ketrampilan melakukan pemecahan masalah, (2) belajar model peraturan orang dewasa (adult role behaviors), dan (3) ketrampilan belajar mandiri (skills for independent learning). Peserta didik yang melakukan inkuiri dalam pembelajaran akan menggunakan ketrampilan berpikir tingkat tinggi (higher-order thinking skill) dimana mereka akan melakukan operasi mental seperti induksi, deduksi, klasifikasi, dan reasoning. Karakteristik lingkungan belajar model pembelajaran Problem Based Learning (PBL) adalah: keterbukaan, keterlibatan peserta didik secara aktif, dan atmosfir kebebasan intelektual.

Hasil belajar dalam pembelajaran dilanjutkan dengan penilaian pengetahuan diperoleh dari penilaian harian (UH). Dalam penelitian ini hasil belajar akan mengambil 
hasil nilai ulangan harian dari materi pengaruh perubahan dan interaksi keruangan terhadap kehidupan negara negara ASEAN

Slameto (2002:39) berpendapat bahwa kegiatan belajar mengajar semua perlu di evaluasi. Evaluasi dapat memberi motivasi siswa, mereka akan lebih giat belajar meningkatkan proses berfikirnya. Dalam evaluasi ini dapat mengetahui prestasi dan kemajuan siswa, sehingga dapat bertindak yang cepat apabila terjadi kesulitan belajar. Evaluasi dapat menggambarkan kemajuan siswa, sehingga guru dapt mengetahui tingkat perkembangan motivasi terhadap mata pelajatan IImu pengetahuan Sosial terutama dalam materi pengaruh perubahan dan interaksi keruangan dalam kehidupan negara - negara ASEAN

Yang terpenting dalam evaluasi pembelajaran dapat meningkatkan motivasi dan hasil belajar dan berorientasi pada penguasaan ilmu pengetahuan dan teknologi, serta meningkatkan iman dan taqwa. Pada prinsipnya siswa mempunyai motivasi dari dalam dirinya untuk minat belajar karena tentang pengaruh perubahan dan interaksi keruangan terhadap kehidupan negara negara ASEAN. tentang pengaruh perubahan dan interaksi keruangan terhadap kehidupan negara negara ASEAN.

\section{KESIMPULAN}

Pembelajaran yang menggunakan model pembelajaran Problem Based Learning (PBL) merupakan model pembelajaran yang sesuai dengan kurikulum 2013 yang dapat meningkatkan motivasi dan hasil belajar yang terkait dengan pembelajaran Ilmu Pengetahuan Sosial (IPS) dalam materi pengaruh perubahan dan keruangan terhadap kehidupan negara - negara ASEAN.

\section{DAFTAR RUJUKAN}

Dohar., R.W. 1988. Teori- Teori Belajar. Jakarta: P2LPTK Ditjen Dikti Depdikbud Entang, M. dkk., Pengelolaan Kelas. Jakarta: PPLPTK, Depdikbud RI

Hartono, R, 2013, Ragam Model mengajar yang Mudah Diterima Murid, Jogjakarta: Diva Press (Anggota IKAPI)

Hemalik, Oemar. 1986. Media pendidikan. Bandung: Alumni

Iwan S, Retno K, Suciati, A Mushlih, 2018, Buku Guru : Ilmu Pengetahuan Sosial, edisi revisi, Jakarta: Pusat Kurikulum dan Perbukuan, balitbang, Kementrian Pendidikan dan Kebudayaan

Nana Sudjana \& Ibrahim, Penelitian dan Penilaian Pendidikan, Sinar Baru Argensindo, Bandung, 2004.

Ruseffendi. (1998), Statistika Dasar untuk Penelitian Pendidikan. Bandung : IKIP Bandung Press.

Slameto, 2010, Belajar dan Faktor Faktor yang Mempengaruhinya, Jakarta : PT. Rineka Cipta

Saroni, M, Personal Branding Guru: meningkatkan Kualitas dan Profesionalitas Guru, Jogjakarta: Ar-Ruzz Media

Sulaiman, 2019, Guru yang Dirindu Di Abad 21, Jawa Timur: CV. Beta Aksara (Anggota IKAPI)

Yaumi, M, 2012, Pembelajaran Berbasis Multiple Intelegences, Jakarta: PT. Dian Rakyat 